\title{
IMPLEMENTASI MODEL KOOPERATIF TPS MENINGKATKAN AKTIVITAS HASIL BELAJAR PASSING BOLA VOLI
}

\author{
Charly Charles Johnry Koloay ${ }^{1, *}$ \\ ${ }^{1}$ Jurusan Pendidikan Jasmani, Kesehatan dan Rekreasi, Universitas Pendidikan Ganesha
}

\begin{abstract}
Abstrak
Penelitian ini bertujuan untuk meningkatkan aktivitas dan hasil belajar teknik dasar passing bola voli pada siswa kelas XI MIPA 4 SMA Negeri 2 Singaraja tahun pelajaran 2017/2018. Penelitian ini merupakan penelitian tindakan kelas, yaitu guru sebagai peneliti. Penelitian tindakan kelas ini dilaksanakan dalam dua siklus. Subjek penelitian yaitu siswa kelas XI MIPA 4 SMA Negeri 2 Singaraja tahun pelajaran 2017/2018, yang berjumlah 36 siswa dengan rincian 15 siswa putri dan 21 siswa putra. Data dianalisis menggunakan analisis statistik deskriptif. Hasil analisis data hasil penelitian didapatkan aktivitas belajar teknik passing bola voli mengalami peningkatan $1.62 \%$ pada observasi awal ke siklus I. Kemudian meningkat sebesar $0.84 \%$ dari siklus I ke siklus II. Dan meningkat sebesar $2.46 \%$ dari observasi awal ke siklus II. Hasil belajar teknik dasar passing bola voli pada aspek pengetahuan mengalami peningkatan sebesar 55,6\% dari observasi awal ke siklus I. Kemudian meningkat sebesar $22.2 \%$ dari siklus I ke siklus II. Dan meningkat sebesar 77,8\% dari observasi awal ke siklus II, Sedangkan Hasil belajar teknik dasar passing bola voli pada aspek keterampilan mengalami peningkatan sebesar $72.2 \%$ dari observasi awal ke siklus I. Kemudian meningkat sebesar 11,1\% dari siklus I ke siklus II. Dan meningkat sebesar 83,3\% dari observasi awal ke siklus II. Disimpulkan bahwa aktivitas dan hasil belajar passing bola voli (passing bawah dan passing atas) meningkat melalui penerapan model pembelajaran kooperatif tipe TPS pada siswa kelas XI MIPA 4 SMA Negeri 2 Singaraja tahun pelajaran 2017/2018. Peneliti menyarankan agar guru PJOK menggunakan model pembelajaran tipe TPS karena dapat meningkatkan aktivitas dan hasil belajar teknik dasar passing bola voli.
\end{abstract}

\section{Pendahuluan}

Meningkatnya kualitas bangsa salah satunya ditentukan oleh tingkat pendidikan yang dimiliki oleh sumber daya manusia (SDM). Pendidikan merupakan bagian integral dalam pembangunan dan peningkatan kualitas bangsa. Proses pendidikan tak dapat dipisahkan dari proses pembangunan itu sendiri, Pembangunan diarahkan dan bertujuan untuk mengembangkan sumber daya manusia dan pembangunan sektor ekonomi, yang satu dengan lainnya saling berkaitan dan berlangsug dengan berbarengan. Berbicara tentang pendidikan sudah tentu tak dapat dipisahkan dengan semua upaya yang harus dilakukan untuk mengembangkan sumber daya manusia yang berkualitas, sedangkan manusia yang berkualitas dapat dilihat dapat dilihat dari segi pendidikan, telah terkandung secara jelas dalam tujuan pendidikan nasional.

Mutu pendidikan merupakan bahan pertimbangan yang selalu menarik dibicarakan tidak hanya oleh pakar pendidikan tetapi juga oleh masyarakat luas. Terlebihnya lagi pendidikan jasmani olahraga dan kesehatan (PJOK), karena PJOK merupakan sebuah mata pelajaran akademik atau aspek dalam proses pendidikan yang berkenaan dengan perkembangan kemampuan gerak individu serta berhubungan langsung dengan respon mental dan sosial. Guru harus dapat mengajarkan berbagai keterampilan gerak dasar, teknik dan strategi permainan/olahraga, internalisasi nilai-nilai (sportifitas, jujur, kerjasama, dan lain-lain) dari pembiasaan pola hidup sehat. Belajar sebagai konsep mendapatkan pengetahuan dalam praktetknya banyak dianut. "Belajar adalah perubahan disposisi atau kemampuan yang dicapai seseorang melalui aktivitas. Perubahan disposisi tersebut bukan diperoleh langsung dari proses pertumbuhan 
seseorang secara alamiah" (Suprijono, 2009:2). Seiring dengan adanya perubahan kurikulum dan pengembangan model pembelajaran, maka dari itu diperlukan adaptasi baru oleh seorang guru dan peserta didik dalam melakukan proses belajar mengajar (PBM). Untuk membantu peserta didik dalam melakukan adaptasi terhadap perubahan kurikulum dalam proses belajar mengajar maka diperlukan model pembelajaran yang menarik untuk memperlancar adanya stimulus dan respon pada peserta didik.

Berdasarkan observasi awal yang peneliti lakukan di SMA Negeri 2 Singaraja pada hari selasa tanggal 10 agustus 2017 yang bertempat di Lapangan SMA Negeri 2 Singaraja, pada materi teknik lompat jauh berjalan di udara, hal yang sama juga dilakukan oleh guru mata pelajaran PJOK di kelas XI MIPA 4 berjumlah 36 orang dalam materi keterampilan gerak passing dalam permainan bola voli. Setelah meminta peserta didik melakukan pemanasan, guru memberikan materi secara lisan dengan metode ceramah. Kemudian guru memberikan contoh secara langsung yang dilanjutkan dengan latihan di bawah pengawasan guru. Dengan langkah-langkah mengajar seperti ini ditemukan bahwa persentase aktivitas dan hasil belajar peserta didik kelas SMA Negeri 2 Singaraja pada materi keterampilan gerak passing dalam permainan bola voli masih tergolong kurang aktif. Ini dikarenakan tidak terpenuhinya aspek aktivitas belajar sehingga berdampak pada hasil belajar peserta didik yang belum memenuhi standar ketuntasan belajar. Dominasi guru dalam proses pembelajaran masih terlihat, sehingga menyebabkan peserta didik lebih banyak bengong serta banyak peserta didik yang mengobrol ketika guru menjelaskan maupun mendemonstrasikan gerakan, akibat dari proses pembelajaran yang kurang menarik.

Dilihat dari persentase aktivitas keterampilan gerak passing dalam permainan bola voli yang terdiri dari visual, lisan, mendengarkan, metrik, mental dan emosional sebagai berikut: tidak ada peserta didik yang memperoleh nilai sangat aktif tidak ada , aktif sebanyak 16 orang (44,4\%), cukup aktif sebanyak 13 orang $(36,1 \%)$, kurang aktif sebanyak 3 orang $(8,3 \%)$ dan siswa dalam kategori sangat kurang aktif sebanyak 4 orang $(11,1 \%)$. Sehingga aktivitas belajar peserta didik secara klasikal di SMA Negeri 2 Singaraja baru terpenuhi sebanyak 6,25, angka ini berada pada kriteria $5 \mathrm{X}<7$ dengan kategori cukup aktif dilihat dari pedoman penggolongan aktivitas belajar, sehingga aktiitas belajar peserta didik dikatakan belum berhasil. Aktivitas belajar peserta didik dikatakan berhasil minimal berada pada kategori aktif dengan kriteria $7 \quad \mathrm{X}<9$. Maka dari itu, aktivitas belajar peserta didik masih perlu dilakukan perbaikan, sehingga aktivitas belajar peserta didik akan lebih meningkat.

Permasalahan lain terdapat pada hasil belajar keterampilan gerak passing dalam permainan bola voli yang meliputi 2 aspek yaitu aspek pengetahuan dan keterampilan, jika dilihat dari ketuntasan hasil belajar yang berpedoman pada kriteria ketuntasan belajar (KB) nilai mata pelajaran PJOK SMA Negeri 2 Singaraja, Peserta didik yang tuntas pada aspek Pengetahuan sebanyak 8 orang (22\%), dan siswa yang tidak tuntas sebanyak 28 orang (78\%). Peserta didik yang berada pada kategori yang berada pada kategori sangat baik dan baik tidak ada, siswa dalam kategori cukup baik sebanyak 8 orang (22\%), dan siswa dalam kategori kurang baik sebanyak 28 orang (78\%). Dengan menganalisis data hasil belajar peserta didik secara keseluruhan, terlihat persentase ketuntasan belajar aspek pengetahuan peserta didik secara klasikal yaitu 68 angka ini termasuk dalam kategori kurang dilihat dari pedoman penggolongan hasil belajar teknik keterampilan gerak passing dalam permainan bola voli. Peserta didik yang tuntas pada aspek Keterampilan sebanyak 6 orang (17\%), dan siswa yang tidak tuntas sebanyak 30 orang (83\%). Peserta didik yang berada pada kategori yang berada pada kategori sangat baik dan baik tidak ada, siswa dalam kategori cukup baik sebanyak 6 orang (17\%), dan siswa dalam kategori kurang baik sebanyak 30 orang (83\%). Dengan menganalisis data hasil belajar peserta didik secara keseluruhan, terlihat persentase ketuntasan belajar aspek keterampilan peserta didik secara klasikal yaitu 66.07 angka ini termasuk dalam kategori kurang dilihat dari pedoman penggolongan hasil belajar teknik keterampilan gerak passing dalam permainan bola voli.

Dengan menganalisa data hasil belajar peserta didik secara keseluruhan terlihat hasil belajar masih tergolong rendah dan kurang, sehingga belum memenuhi Kriteria Ketuntasan Minimal (KKM) sekolah yaitu 70. Melihat kenyataan tersebut maka peran guru PJOK sebagai pendidik perlu mendapat perhatian khusus di dalam implementasi model pembelajaran yang tepat, karena dengan implementasi model pembelajaran yang tepat akan dapat memacu semangat para peserta didik didalam mengikuti pelajaran dan mendorong peserta didik membuat relasi antara pengetahuan yang dimiliki dengan pengetahuan yang didapat dari sekolah sehingga para peserta didik akan bersikap aktif dalam mengikuti proses pelajaran kususnya pelajaran PJOK pada materi keterampilan gerak passing dalam permainan bola voli, untuk itu dalam meningkatkan kualitas pembelajaran teknik keterampilan gerak passing dalam permainan bola voli diharapkan guru PJOK mampu menguasai dan melaksanakan beraneka ragam model atau teknik penyampaian materi yang tepat menarik yang nantinya dapat mendorong minat belajar peserta didik sehingga peserta didik tidak merasa jenuh dan merasa cepat bosan dalam mengikuti pelajaran. 
Permasalahan yang ditemukan pada saat observasi awal pada proses pembelajaran keterampilan gerak passing dalam permainan bola voli belum memenuhi target. Faktor-faktor yang menyebabkan hasil belajar belum berhasil tuntas yaitu, terdapat banyak siswa yang minat dan belajarnya kurang terhadap mata pelajaran pendidikan jasmani, olahraga dan kesehatan khususnya pada materi pasing bola voli. Ini ditandai dengan gerak siswa kurang aktif didalam mengamati demonstrasi yang diperagakan oleh guru mengenai materi passing bola voli sehingga sebagian besar siswa tidak dapat melakukan gerak permulaan, gerak pelaksanaan dan gerak lanjutan dengan teknik yang benar, semangat yang ditonjolkan juga kurang dan siswa kurang sunguh-sungguh didalam melakukan gerakan.

Dilihat dari uraian di atas penulis akan mencoba memberikan salah satu alternatif pemecahan masalah yaitu dengan menerapkan model pembelajaran kooperatif tipe TPS. Adapun keunggulan dari model pembelajaran kooperatif tipe TPS yaitu melibatkan semua peserta didik secara langsung dalam KBM, setiap peserta didik dapat menguji tingkat pengetahuan dan penguasaan bahan pelajaran masingmasing, dapat menumbuhkan dan mengembangkan sikap berfikir, dapat memperoleh kepercayaan dan kemampuan berfikir serta dapat menunjang sikap-sikap sosial dan sikap demokratis para peserta didik.

Penelitian ini didukung oleh hasil penelitian dari peneliti-peneliti sebelumnya diantaranya:

(1)Arimbawa (2014) menemukan bahwa "Aktivitas dan hasil belajar teknik dasar passing bola voli meningkat melalui implementasi model pembelajaran kooperatif tipe TPS pada peserta didik kelas I RPL SMKN 1 Gianyar tahun pelajaran 2013/2014."(2) Bayu Saputra (2014) menemukan bahwa "Aktivitas dan hasil belajar passing bola basket meningkat melalui penerapan model pembelajaran kooperatif tipe TPS pada peserta didik kelas VIIIB SMPN 1 Seririt tahun pelajaran 2013/2014", (3) Juli Antara (2012) menemukan bahwa "Aktivitas dan hasil belajar teknik dasar passing bola voli meningkat melalui implementasi model pembelajaran kooperatif tipe TPS pada peserta didik kelas VII G SMP Negeri 2 Selat tahun pelajaran 2012/2013". (4) Warniki (2014) menemukan bahwa "Aktivitas dan hasil belajar teknik dasar berguling (roll) meningkat melalui implementasi model pembelajaran kooperatif tipe TPS pada peserta didik kelas VIIB SMPN 6 Singaraja tahun pelajaran 2013/2014", (5) Wardana (2015) menemukan bahwa "Aktivitas dan hasil belajar teknik passing bola voli meningkat melalui implementasi model pembelajaran kooperatif tipe TPS pada peserta didik kelas IXIB SMPN 3 Tejakula tahun pelajaran 2014/2015", Berdasarkan pemaparan di atas, peneliti mencoba melakukan penelitian dengan judul "Implementasi Model Pembelajaran Kooperatif Tipe Think Pair Share (TPS) Untuk Meningkatkan Aktivitas dan Hasil Belajar Teknik Keterampilan gerak passing dalam permainan bola voli Pada Peserta didik Kelas XI MIPA 4 SMA Negeri 2 Singaraja Tahun Pelajaran 2017/2018”.

\section{Metode}

Jenis penelitian yang akan digunakan dalam penelitian ini adalah penelitian tindakan kelas (classroom action research). "Penelitian tindakan kelas didefinisikan sebagai suatu bentuk penelitian yang bersifat refletif dengan melakukan tindakan-tindakan tertentu agar dapat memperbaiki dan atau meningkatkan praktek-praktek pembelajaran di kelas secara lebih profesional" (Kanca, I Nyoman, 2010:108).

Kanca, I Nyoman, 2010:110 menjelaskan, Tujuan PTK adalah untuk meningkatkan dan atau perbaikan praktek pembelajaran yang seharusnya dilakukan oleh guru. PTK merupakan salah satu cara yang strategis bagi guru untuk meningkatkan dan atau memperbaiki layanan pendidikan bagi guru dan dalam konteks pembelajaran dikelas. Dasar utama bagi dilaksankannya PTK adalah untuk perbaikan.kata perbaikan disini terkait dan memiliki konteks dengan proses pembelajaran.

Borg (dalam Kanca, I Nyoman,2010:110) menyatakan, Bahwa tujuan utama dalam PTK sebagai pengembangan keterampilan guru berdasarkan pada persoalanan-persoalan pembelajaran yang dihadapi oleh guru di kelasnya sendiri, dan bukannya bertujuan untuk pencapaian pengetahuan umum dalam bidang pendidikan. "Terdapat empat bentuk penelitian tindakan kelas, yaitu sebagai berikut a. guru sebagai peneliti b.penelitian tindakan kolaboratif c.simultan terintegrasi d.adminitrasi sosial eksperimental" Oja SN dalam (Kanca I Nyoman, 2010: 115)

Pelaksanaan dalam penelitian ini, jenis atau bentuk penelitian tindakan yang akan digunakan oleh peneliti adalah guru sebagai peneliti dalam hal ini, peneliti belum menjadi seorang guru maka peneliti disini yang bertindak sebagai guru. Guru sebagai peneliti seyogyanya memiliki dan mempunyai andil atau peran penting dan terlibat secara penuh dala proses PTK yang memiliki fungsi untuk merancang rencana pembelajaran, melaksanakan pembelajaran, melakukan observasi dan refleksi dalam proses pembelajaran. Penelitian ini, untuk memperbaiki kinerja peserta didik dalam meningkatkan aktifitas dan hasil belajar melalui implementasi model pembelajaran koopratif tipe TPS pada pembelajaran teknik keterampilan gerak passing dalam permainan bola voli. Penelitian tindakan kelas pada pengajaran 
merupakan salah satu cara untuk menjadikan pembelajaran menjadi lebih efektif dan efesien yang akan dilihat dari kamajuan yang telah dicapai oleh peserta didik.penelitian ini, direncanakan menggunakan dua siklus hal tersebut

dilakukan karena berdasarkn syarat penelitian tindakan kelas yaitu terdiri dari beberapa siklus, dilakukan untuk memecahkan permasalahan dilapangan. Setiap siklus dalam proses belajar mengajar, dilaksanakan untuk memperbaiki proses belajar mengajar dalam hal pencapaian hasil belajar serta berpedoman pada kurikulum yang sudah disesuaikan dan ditetapkan oleh sekolah.

\section{Hasil dan Pembahasan}

Penelitian ini dilaksanakan dalam 2 siklus. Siklus I dilaksanakan untuk meningkatkan aktivitas dan hasil belajar teknik dasar passing bola voli yang dilaksanakan sebanyak 2 kali pertemuan, yaitu pada hari Rabu, tanggal 2 Agustus 2017 memberikan tindakan dan observasi aktivitas belajar siklus I dengan materi passing bawah dan passing atas bola voli. Sedangkan hari Rabu, tanggal 9 Agustus 2017 memberikan observasi aktivitas dan mengevaluasi hasil belajar teknik dasar passing bawah dan passing atas bola voli, pada pukul 05.30 - 07.15 di lapangan bola basket SMA Negeri 2 Singaraja. Siklus II dilaksanakan untuk meningkatkan aktivitas dan hasil belajar teknik dasar passing bola voli pada siklus I yang dilaksanakan sebanyak 2 kali pertemuan, yaitu pada hari Rabu, tanggal 16 Agustus 2017 memberikan tindakan dan observasi aktivitas belajar siklus II dengan materi teknik dasar passing bawah dan passing atas bola voli. Sedangkan hari Rabu, tanggal 23 Agustus 2017 memberikan observasi aktivitas dan mengevaluasi hasil belajar teknik dasar passing bawah dan passing atas bola voli pada pukul $05.30-07.15$ di lapangan basket SMA Negeri 2 Singaraja.

Berdasarkan hasil analisis data pada siklus I, maka adapun kriteria pengolongan tentang aktivitas belajar pada siklus I adalah yang tertuang dalam Tabel 1 sebagai berikut.

Tabel 1 Kategori Penggolongan Aktivitas Belajar Teknik Dasar Passing Bola Voli pada Siklus I

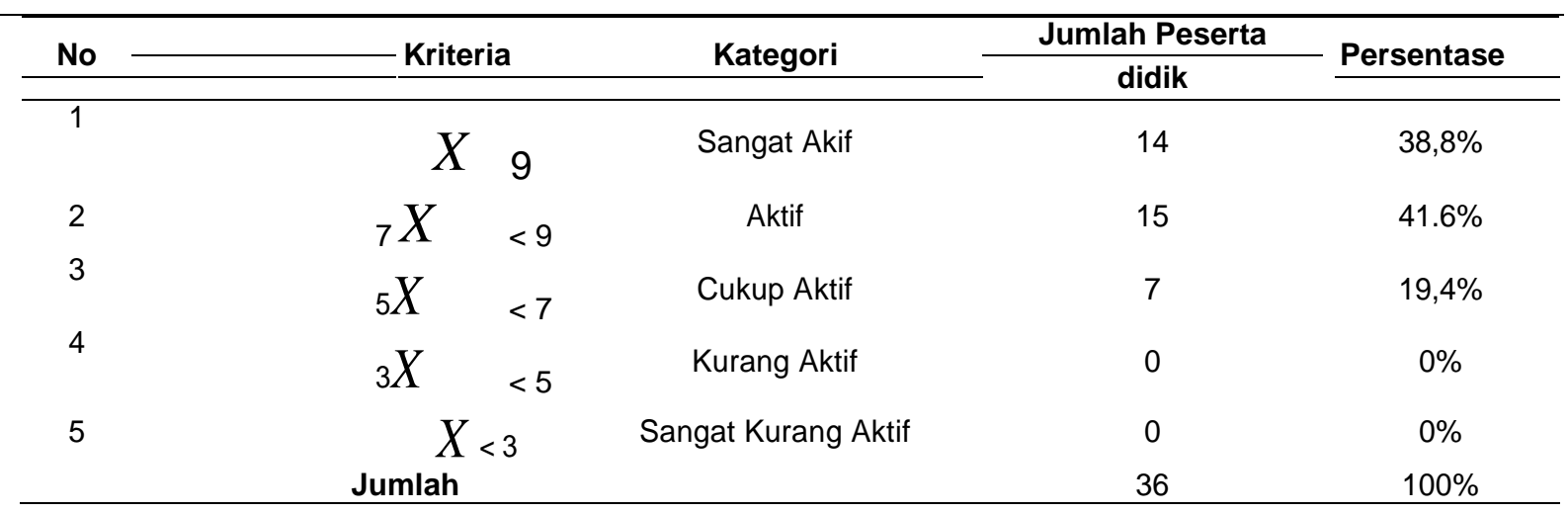

Berdasarkan tabel 1 dapat dipaparkan bahwa, peserta didik dengan kategori sangat aktif sebanyak 14 orang $(38,8 \%)$, peserta didik dengan kategori aktif sebanyak 15 orang (41.6\%), peserta didik dengan kategori cukup aktif sebanyak 7 orang (19.4\%), peserta didik dengan kategori kurang aktif tidak ada $(0 \%)$, peserta didik dengan kategori sangat kurang aktif tidak ada $(0 \%)$.

Dari hasil analisis aktivitas belajar teknik dasar passing bola voli, diketahui 7 orang yang berada dalam katagori cukup aktif. Adapun permasalahannya yaitu : peserta didik belum mengamati guru dalam mendemonstrasikan teknik dasar passing bola voli, peserta didik belum berani mengemukakan pendapat dan memberikan saran dalam diskusi, peserta didik belum melakukan percobaan gerakan-gerakan baru untuk membatu menyempurnakan gerakan, dan peserta didik belum percaya diri dalam menghadapi dan memecahkan masalah. Tindakan-tindakan yang dilakukan untuk mengatasi permasalahan tersebut adalah :menekankan pemahaman model pembelajaran kooperatif, memotivasi peserta didik kembali agar lebih bersemangat dan aktif mengikuti pembelajaran, dan memperbanyak kelompok dan memperkecil anggota kelompok.

Hasil data pada tabel 1 berdasarkan dari obsevasi hasil tindakan yang dilakukan oleh observer tentang aktivitas belajar peserta didik pada siklus I, adapun nilai rata-rata aktivitas belajar secara klasikal yaitu. 


$$
\begin{gathered}
X=\quad \underline{x} \\
\quad N \\
283,5_{36} \quad 7,87
\end{gathered}
$$

Hasil 7,87 jika dimasukan kedalam kategori yang telah dibuat pada bab III tentang pedoman penggolongan aktivitas belajar peserta didik pada siklus I termasuk ke dalam kategori aktif. Berdasarkan analisis data pada siklus I maka dapat dikelompokkan dalam katagori sebagai berikut.

Tabel 2 Persentase Ketuntasan Hasil Belajar aspek pengetahuan Teknik Dasar Passing Bola voli

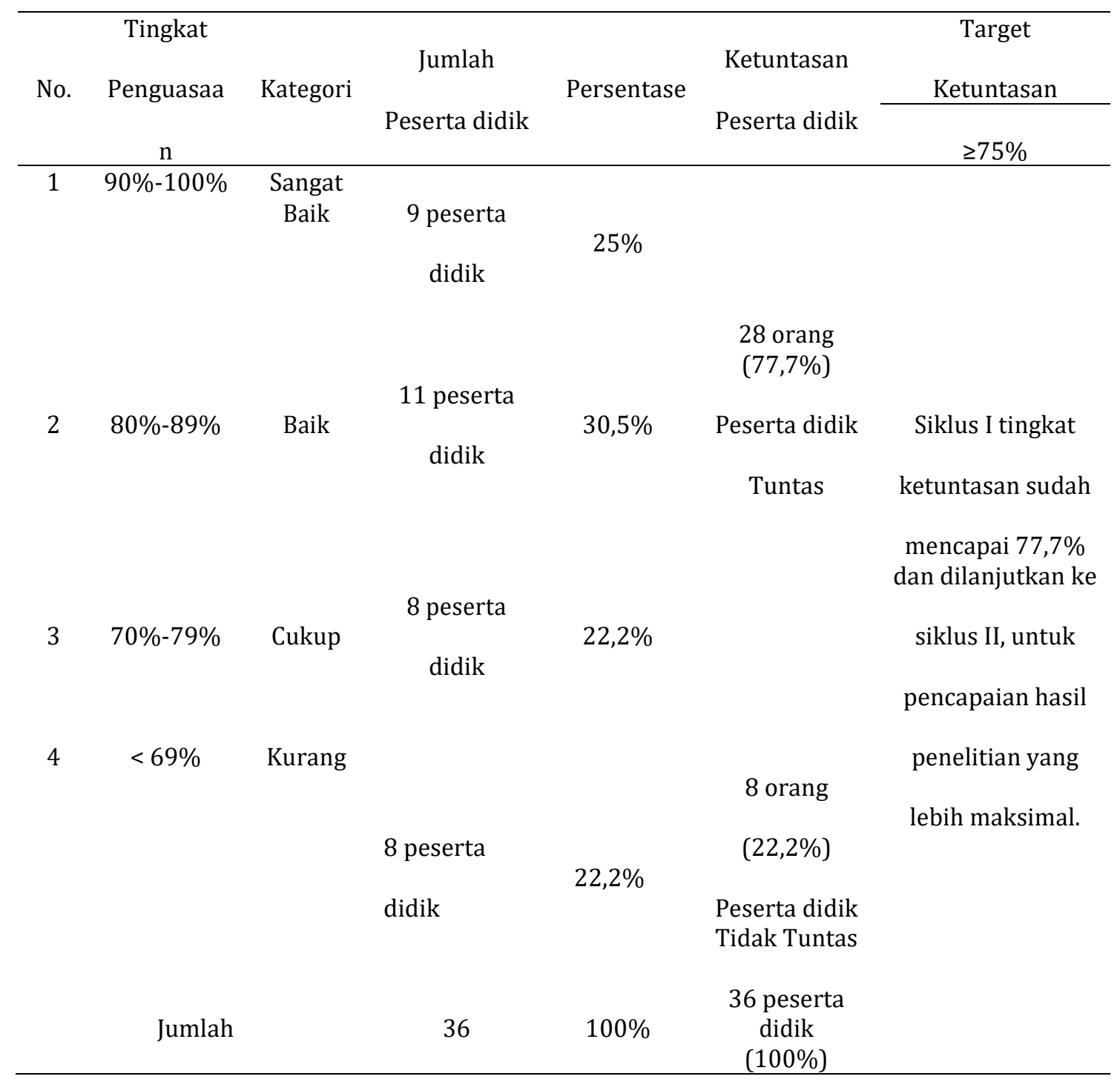

Berdasarkan tabel 4.2 dapat dipaparkan bahwa, peserta didik yang tuntas sebanyak 28 orang $(77,7 \%)$ dan peserta didik yang tidak tuntas sebanyak 8 orang $(22,2 \%)$. Adapun rinciannya sebagai berikut : 9 peserta didik (25\%) dengan kategori sangat baik, 11 peserta didik $(30,6 \%)$ dengan kategori baik, 8 peserta didik $(22,2 \%)$ dengan kategori cukup, 8 peserta didik (22,2\%) dengan kategori kurang baik. 
Tabel 3 Persentase Ketuntasan Hasil Belajar aspek Keterampilan Teknik Dasar Passing Bola voli pada Peserta didik Kelas XI MIPA 4 SMA Negeri 2 Singaraja pada Siklus I.

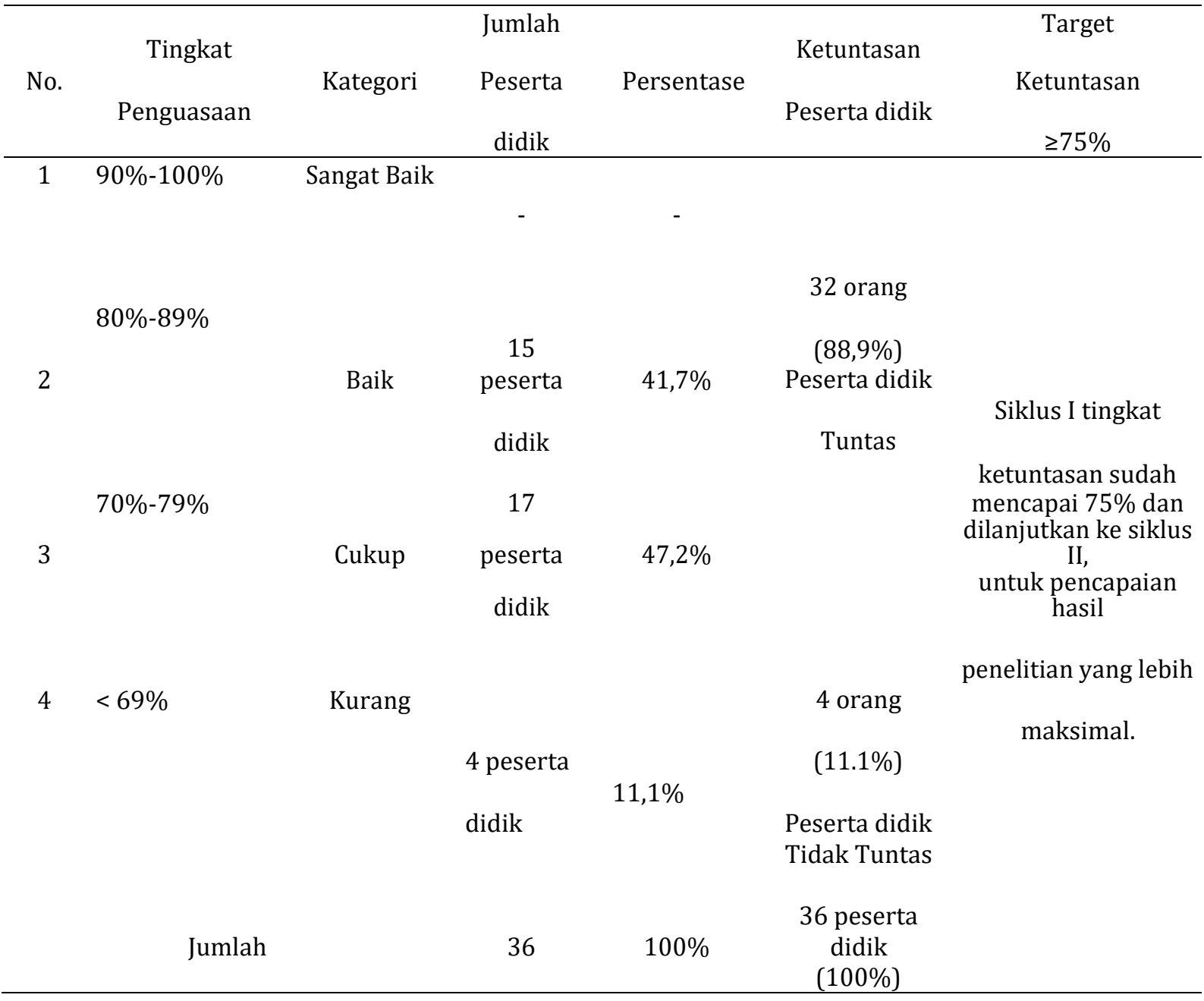

Berdasarkan tabel 3 dapat dipaparkan bahwa, peserta didik yang tuntas sebanyak 32 orang $(88,9 \%)$ dan peserta didik yang tidak tuntas sebanyak 4 orang $(11,1 \%)$. Adapun rinciannya sebagai berikut : belum ada peserta didik dengan kategori sangat baik, 15 peserta didik $(41,7 \%)$ dengan kategori baik, 17 peserta didik (47,2\%) dengan kategori cukup, 4 peserta didik $(11,1 \%)$ dengan kategori kurang, dan tidak ada peserta didik (0\%) dengan kategori sangat kurang.

Berdasarkan pemaparan tersebut, kategori penggolongan hasil belajar aspek keterampilan teknik dasar passing bola voli pada peserta didik kelas XI MIPA 4 SMA Negeri 2 Singaraja Tahun Pelajaran 2017/2018 juga dapat dilihat pada Gambar 4.3 sebagai berikut.

Dari analisis data hasil belajar teknik dasar passing bola voli pada siklus I terdapat 4 orang yang tidak tuntas. Adapun masalah yang dihadapi peserta didik, antara lain : sikap yang ditunjukkan peserta didik dalam pembelajaran masih belum maksimal, dan kurangnya penguasaan gerakan teknik dasar passing bola voli. Tindakan-tindakan yang dilakukan untuk mengatasi permasalahan tersebut adalah : lebih menekankan kepada peserta didik tentang materi teknik dasar passing bola voli dari gerak permulaan, gerak pelaksanaan, dan gerak lanjutan, memperkecil jumlah anggota dalam satu kelompok sehingga diharapkan dengan jumlah kelompok yang kecil maka proses pembelajaran dapat berjalan lebih efektif.

Dilihat dari analisis data di atas, maka dapat disimpulkan bahwa persentase ketuntasan hasil belajar teknik dasar passing bola voli pada siklus I adalah 88,9\%. Artinya nilai 88,9\% pada tingkat penguasaan hasil belajar teknik dasar passing bola voli siklus I pada peserta didik kelas XI MIPA 4 SMA Negeri 2 Singaraja Tahun Pelajaran 2017/2018 berada pada rentang 80\%-89\% dengan kategori baik (tuntas). Dengan tercapainya hasil belajar peserta didik tersebut maka penelitian ini akan dilanjutkan ke siklus II dengan melihat kekurangan dan permasalahan pada siklus I. Permasalahan yang ditemukan adalah: peserta didik belum mengamati guru dalam mendemonstrasikan teknik dasar passing bola voli, 
peserta didik belum berani mengemukakan pendapat serta memberikan saran dalam diskusi, peserta didik belum melakukan percobaan gerakan-gerakan baru untuk membatu menyempurnakan gerakan dan peserta didik belum percaya diri dalam menghadapi serta memecahkan masalah.

Data Hasil Penelitian Siklus II, Sesuai dengan permasalahan dan tujuan dari penelitian ini, maka hasil yang ingin dicapai pada siklus II ini adalah peningkatan aktivitas dan hasil belajar peserta didik dalam pembelajaran teknik dasar passing bola voli dari siklus I. Adapun hasil yang diproleh adalah sebagai berikut. Berdasarkan hasil analisis siklus II, maka adapun kreteria penggolongan aktivitas belajar peserta didik pada siklus II adalah yang tertuang dalam Tabel 4 berikut.

Tabel 4 Kategori Penggolongan Aktivitas Belajar Teknik Passing Bola Voli pada Siklus II

\begin{tabular}{|c|c|c|c|c|c|}
\hline No & \multicolumn{2}{|c|}{ Kriteria } & Kategori & $\begin{array}{c}\text { Jumlah Peserta } \\
\text { didik }\end{array}$ & Persentase \\
\hline 1 & $X$ & 9 & Sangat Akif & 16 & $44,4 \%$ \\
\hline 2 & ${ }_{7} X$ & $<9$ & Aktif & 18 & $50 \%$ \\
\hline 3 & $5 X$ & $<7$ & Cukup Aktif & 2 & $5,6 \%$ \\
\hline 4 & ${ }_{3} X$ & $<5$ & Kurang Aktif & 0 & $0 \%$ \\
\hline 5 & $\underset{\text { Jumlah }}{X}$ & & Sangat Kurang Aktif & $\begin{array}{c}0 \\
36\end{array}$ & $\begin{array}{c}0 \% \\
100 \%\end{array}$ \\
\hline
\end{tabular}

Berdasarkan tabel 4 dapat dipaparkan bahwa, peserta didik dengan kategori sangat aktif sebanyak 16 orang $(44,4 \%)$, peserta didik dengan kategori aktif sebanyak 18 orang (50\%), peserta didik dengan kategori cukup aktif 2 orang (5,6\%), peserta didik dengan kategori kurang aktif tidak ada (0\%), peserta didik dengan kategori sangat kurang aktif tidak ada $(0 \%)$.

Hasil data pada tabel 4 . berdasarkan dari obsevasi hasil tindakan yang dilakukan oleh peneliti tentang aktivitas belajar peserta didik pada siklus II, adapun nilai rata-rata aktivitas belajar secara klasikal yaitu.

$$
\begin{array}{ll}
313 & \\
& 8,7 \\
N & \frac{36}{36}
\end{array}
$$

Hasil 8,7 jika dimasukan kedalam kategori yang telah dibuat pada bab III tentang pedoman penggolongan aktivitas belajar peserta didik pada siklus II termasuk ke dalam kategori aktif. Berdasarkan analisis data pada siklus II maka dapat dikelompokkan dalam kategori sebagai berikut.

Tabel 5 Presentase Ketuntasan Hasil Belajar aspek pengetahuan Teknik Dasar Passing Bola Voli pada

\begin{tabular}{|c|c|c|c|c|c|c|}
\hline No. & $\begin{array}{c}\text { Tingkat } \\
\text { Penguasaan }\end{array}$ & Kategori & $\begin{array}{c}\text { Jumlah } \\
\text { Peserta didik }\end{array}$ & Persentase & $\begin{array}{l}\text { Ketuntasan } \\
\text { Peserta didik }\end{array}$ & $\begin{array}{c}\text { Target } \\
\text { Ketuntasan } \\
\geq 75 \%\end{array}$ \\
\hline 1 & $90 \%-100 \%$ & $\begin{array}{l}\text { Sangat } \\
\text { Baik }\end{array}$ & $\begin{array}{l}11 \text { peserta } \\
\text { didik }\end{array}$ & $30,6 \%$ & \multirow{3}{*}{$\begin{array}{c}36 \text { orang } \\
(100 \%) \text { Peserta } \\
\text { didik Tuntas }\end{array}$} & $\begin{array}{l}\text { Siklus II tingkat } \\
\text { ketuntasan sudah }\end{array}$ \\
\hline 2 & $80 \%-89 \%$ & Baik & $\begin{array}{l}22 \text { peserta } \\
\text { didik }\end{array}$ & $61,1 \%$ & & $\begin{array}{c}\text { mencapai } 100 \% \text { dan } \\
\text { penelitian dihentikan } \\
\text { sesuai dengan }\end{array}$ \\
\hline 3 & $70 \%-79 \%$ & Cukup & $\begin{array}{l}3 \text { peserta } \\
\text { didik }\end{array}$ & $8,3 \%$ & & perencanaan awal \\
\hline 4 & $<69 \%$ & Kurang & - & & $\begin{array}{l}0 \text { Peserta didik } \\
\text { Tidak Tuntas }\end{array}$ & \\
\hline & Jumlah & & 36 & $100 \%$ & $\begin{array}{c}36 \text { peserta didik } \\
(100 \%)\end{array}$ & \\
\hline
\end{tabular}
Peserta didik Kelas XI 4 SMA Negeri 2 Singaraja pada Siklus II.

Berdasarkan tabel 5 dapat dipaparkan bahwa, peserta didik yang tuntas sebanyak 36 orang (100\%) dan peserta didik yang tidak tuntas tidak ada (0\%). Adapun rinciannya sebagai berikut : 11 orang peserta 
didik (30.5\%) dengan kategori sangat baik, 22 orang peserta didik $(61,1 \%)$ dengan kategori baik, 3 orang peserta didik $(8,3 \%)$ dengan kategori cukup, dan tidak ada (0\%) dengan kategori kurang.

Dilihat dari analisis data di atas, maka dapat disimpulkan bahwa persentase ketuntasan hasil belajar teknik dasar passing bola voli pada siklus II adalah 100\%. Artinya nilai 100\% pada tingkat penguasaan hasil belajar teknik dasar passing bola voli siklus II pada peserta didik kelas XI MIPA 4 SMA Negeri 3 Singaraja Tahun Pelajaran 2017/2018 berada pada rentang 85\%-100\% dengan kategori sangat baik (tuntas).

Tabel 6 Presentase Ketuntasan Hasil Belajar aspek Keterampilan Teknik Dasar Passing Bola Voli pada Peserta didik Kelas XI MIPA 4 SMA Negeri 2 Singaraja pada Siklus II.

\begin{tabular}{|c|c|c|c|c|c|c|}
\hline No. & $\begin{array}{c}\text { Tingkat } \\
\text { Penguasaan }\end{array}$ & Kategori & $\begin{array}{l}\text { Jumlah } \\
\text { Peserta } \\
\text { didik }\end{array}$ & $\begin{array}{l}\text { Persenta } \\
\text { se }\end{array}$ & $\begin{array}{l}\text { Ketuntasan } \\
\text { Peserta didik }\end{array}$ & $\begin{array}{c}\text { Target } \\
\text { Ketuntasan } \\
\geq 75 \%\end{array}$ \\
\hline 1 & $90 \%-100 \%$ & $\begin{array}{l}\text { Sangat } \\
\text { Baik }\end{array}$ & $\begin{array}{l}3 \text { peserta } \\
\text { didik }\end{array}$ & $8,3 \%$ & & \\
\hline 2 & $78 \%-89 \%$ & Baik & $\begin{array}{l}29 \text { peserta } \\
\text { didik }\end{array}$ & $80,6 \%$ & $\begin{array}{c}36 \text { orang } \\
(100 \%) \text { Peserta }\end{array}$ & Siklus II tingkat \\
\hline 3 & $75 \%-77 \%$ & Cukup & $\begin{array}{l}4 \text { peserta } \\
\text { didik }\end{array}$ & $11,1 \%$ & didlk I untas & $\begin{array}{l}\text { ketuntasan sudah } \\
\text { mencapai } 100 \% \text { dan }\end{array}$ \\
\hline 4 & $<75 \%$ & Kurang & - & - & $\begin{array}{l}0 \text { Peserta didik } \\
\text { Tidak Tuntas }\end{array}$ & $\begin{array}{c}\text { penelitian dihentikan } \\
\text { sesuai dengan } \\
\text { perencanaan awal }\end{array}$ \\
\hline & Jumlah & & 36 & $100 \%$ & $\begin{array}{c}36 \text { peserta didik } \\
(100 \%)\end{array}$ & \\
\hline
\end{tabular}

Berdasarkan tabel 6 dapat dipaparkan bahwa, peserta didik yang tuntas sebanyak 36 orang (100\%) dan peserta didik yang tidak tuntas tidak ada ( $0 \%)$. Adapun rinciannya sebagai berikut : 3 orang peserta didik $(8,3 \%)$ dengan kategori sangat baik, 29 orang peserta didik $(80,5 \%)$ dengan kategori baik, 4 orang peserta didik (11,1\%) dengan kategori cukup, dan tidak ada (0\%) dengan kategori kurang.

Dilihat dari analisis data di atas, maka dapat disimpulkan bahwa persentase ketuntasan hasil belajar teknik dasar passing bola voli pada siklus II adalah 100\%. Artinya nilai 100\% pada tingkat penguasaan hasil belajar teknik dasar passing bola voli siklus II pada peserta didik kelas XI MIPA 4 SMA Negeri 2 Singaraja Tahun Pelajaran 2017/2018 berada pada rentang 90\%-100\% dengan kategori sangat baik (tuntas).

Peningkatan aktivitas belajar peserta didik dari observasi awal sampai dengan siklus II, disajikan dalam Tabel 7 berikut.

Tabel 7 Ringkasan Data Aktivitas Belajar Peserta didik

\begin{tabular}{|c|c|c|c|c|c|c|}
\hline \multirow[b]{2}{*}{ No } & \multirow[b]{2}{*}{ Tahapan } & \multirow[b]{2}{*}{$\begin{array}{l}\text { Aktivitas } \\
\text { Belajar } \\
\text { Klasikal } \\
\end{array}$} & \multirow{2}{*}{$\begin{array}{l}\text { Keaktifan } \\
\text { Peserta } \\
\text { didik }\end{array}$} & \multicolumn{3}{|c|}{ Peningkatan Aktivitas Belajar } \\
\hline & & & & $\begin{array}{c}\text { Observasi } \\
\text { Awal ke } \\
\text { Siklus I }\end{array}$ & $\begin{array}{c}\text { Siklus I ke } \\
\text { Siklus II }\end{array}$ & $\begin{array}{l}\text { Observasi Awa } \\
\text { ke Siklus II }\end{array}$ \\
\hline 1. & $\begin{array}{c}\text { Observasi } \\
\text { Awal }\end{array}$ & 6.25 & Cukup Aktif & & & \\
\hline & & & & 1.62 & & \\
\hline 2. & Siklus I & 7,87 & Aktif & & & 2.46 \\
\hline 3. & Siklus II & 8,71 & Aktif & & 0.84 & \\
\hline
\end{tabular}

Berdasarkan Tabel 7 hasil analisis data aktivitas belajar teknik dasar passing bola voli pada peserta didik kelas XI MIPA 4 SMA Negeri 2 Singaraja dapat disampaikan bahwa, aktivitas belajar peserta didik pada observasi awal secara klasikal sebesar 6,25. Kemudian diberikan tindakan pada siklus I menjadi 7,87. Karena pada siklus I aktivitas peserta didik masih perlu ditingkatkan maka diberikan tindakan pada siklus II menjadi 8,71. Dari hasil analisis data tersebut, dapat dilihat terjadi peningkatan aktivitas belajar 
dari observasi awal, siklus I dan siklus II. Aktivitas belajar teknik dasar passing bola voli pada peserta didik kelas XI MIPA 4 SMA Negeri 2 Singaraja mengalami peningkatan sebesar 1,62 dari 6,25 (cukup aktif) pada observasi awal menjadi 7,87 (aktif) pada siklus I. Kemudian meningkat sebesar 0.84 dari 7,87 (aktif) pada siklus I menjadi 8,71 (aktif) pada siklus II. Dan meningkat sebesar 2,46 dari 6,25 (cukup aktif) pada observasi awal menjadi 8,71 (aktif) pada siklus II.

Peningkatan hasil belajar peserta didik dari siklus I sampai dengan siklus II, disajikan dalam tabel 8

Tabel 8 Ringkasan Data Hasil Belajar aspek pengetahuan peserta didik

\begin{tabular}{|c|c|c|c|c|c|c|}
\hline \multirow[b]{2}{*}{ No } & \multirow[b]{2}{*}{ Tahapan } & \multirow[b]{2}{*}{$\begin{array}{l}\text { Persentase } \\
\text { Hasil Belajar }\end{array}$} & \multirow{2}{*}{$\begin{array}{c}\text { Ketuntasan } \\
\text { Peserta } \\
\text { didik }\end{array}$} & \multicolumn{3}{|c|}{ Peningkatan Hasil Belajar } \\
\hline & & & & $\begin{array}{l}\text { Observasi } \\
\text { Awal ke } \\
\text { Siklus I }\end{array}$ & $\begin{array}{c}\text { Siklus I ke } \\
\text { Siklus II }\end{array}$ & $\begin{array}{c}\text { Observasi } \\
\text { Awal ke Siklus } \\
\text { II }\end{array}$ \\
\hline \multirow[t]{2}{*}{1.} & $\begin{array}{c}\text { Observasi } \\
\text { Awal }\end{array}$ & $22,2 \%$ & Tuntas & & & \\
\hline & & & & $55,6 \%$ & & $77,8 \%$ \\
\hline 2. & Siklus I & $77,8 \%$ & Tuntas & & $22.2 \%$ & \\
\hline 3. & Siklus II & $100 \%$ & Tuntas & & & \\
\hline
\end{tabular}

Berdasarkan Tabel 8 hasil analisis data hasil belajar teknik dasar passing bola voli pada peserta didik kelas XI MIPA 4 SMA Negeri 2 Singaraja dapat disampaikan bahwa, persentase hasil belajar peserta didik aspek pengetahuan pada observasi awal sebesar $22,2 \%$. Kemudian diberikan tindakan pada siklus I menjadi $77.8 \%$. Karena pada siklus I masih ada peserta didik yang belum tuntas maka diberikan tindakan pada siklus II menjadi 100\%. Dari hasil analisis data tersebut, dapat dilihat terjadi peningkatan persentase hasil belajar dari observasi awal, siklus I dan siklus II. Persentase hasil belajar teknik dasar passing bola voli pada peserta didik kelas XI MIPA 4 SMA Negeri 2 Singaraja mengalami peningkatan sebesar 55,6\% dari 22,2\% (siswa tuntas) pada observasi awal menjadi 77,8\% (suswa tuntas) pada siklus I. Kemudian meningkat sebesar 22,2\% dari 77,8\% (siswa tuntas) pada siklus I menjadi $100 \%$ (siswa tuntas) pada siklus II. Dan meningkat sebesar 77,8\% dari 22,2\% (siswa tuntas) pada observasi awal menjadi $100 \%$ (tuntas) pada siklus II.

Tabel 9 Ringkasan Data Hasil Belajar aspek keterampilan peserta didik

\begin{tabular}{|c|c|c|c|c|c|}
\hline \multirow[b]{2}{*}{ Tahapan } & \multirow[b]{2}{*}{$\begin{array}{c}\text { Persentase Hasil } \\
\text { Belajar }\end{array}$} & \multirow[b]{2}{*}{$\begin{array}{l}\text { Ketuntasan } \\
\text { Peserta didik }\end{array}$} & \multicolumn{3}{|c|}{ Peningkatan Hasil Belajar } \\
\hline & & & $\begin{array}{c}\text { Observasi Awal } \\
\text { ke Siklus I }\end{array}$ & $\begin{array}{c}\text { Siklus I ke } \\
\text { Siklus II }\end{array}$ & $\begin{array}{c}\text { Observasi Awal ke } \\
\text { Siklus II }\end{array}$ \\
\hline $\begin{array}{l}\text { Observasi } \\
\text { Awal }\end{array}$ & $16,7 \%$ & Tuntas & $72,2 \%$ & & \\
\hline & & & & & $83,3 \%$ \\
\hline Siklus I & $88,9 \%$ & Tuntas & & $11,1 \%$ & \\
\hline Siklus II & $100 \%$ & Tuntas & & & \\
\hline
\end{tabular}

Berdasarkan Tabel 9 hasil analisis data hasil belajar aspek keterampilan teknik dasar passing bola voli pada peserta didik kelas XI MIPA 4 SMA Negeri 2 Singaraja dapat disampaikan bahwa, persentase 
hasil belajar peserta didik aspek keterampilan pada observasi awal sebesar 16,7\%. Kemudian diberikan tindakan pada siklus I menjadi $88,9 \%$. Karena pada siklus I masih ada peserta didik yang belum tuntas maka diberikan tindakan pada siklus II menjadi 100\%. Dari hasil analisis data tersebut, dapat dilihat terjadi peningkatan persentase hasil belajar dari observasi awal, siklus I dan siklus II. Persentase hasil belajar teknik dasar passing bola voli pada peserta didik kelas XI MIPA 4 SMA Negeri 2 Singaraja mengalami peningkatan sebesar $72,2 \%$ dari $16,7 \%$ (siswa tuntas) pada observasi awal menjadi $88.9 \%$ (tuntas) pada siklus I. Kemudian meningkat sebesar $11,1 \%$ dari $89,9 \%$ (siswa tuntas) pada siklus I menjadi 100\% (siswa tuntas) pada siklus II. Dan meningkat sebesar 83,3\% dari 16,7\% (siswa tuntas) pada observasi awal menjadi 100\% (siswa tuntas) pada siklus II

Aktivitas Belajar Pada Siklus I, Berdasarkan hasil observasi dan evaluasi diketahui aktivitas belajar peserta didik pada siklus I dapat dipaparkan bahwa, peserta didik dengan kategori sangat aktif sebanyak 14 orang $(38,8 \%)$, peserta didik dengan kategori aktif sebanyak 15 orang $(41,6 \%)$, peserta didik dengan kategori cukup aktif sebanyak 7 orang $(19,4 \%)$, dan peserta didik dengan kategori kurang aktif tidak ada (0\%). Sedangkan aktivitas belajar secara klasikal diperoleh sebesar 8,71 yang berada pada kategori aktif.

Aktivitas Belajar Pada Siklus II, Berdasarkan hasil observasi dan evaluasi diketahui aktivitas belajar peserta didik pada siklus II dapat dipaparkan bahwa, peserta didik dengan kategori sangat aktif sebanyak 16 orang $(44,4 \%)$, peserta didik dengan kategori aktif sebanyak 18 orang $(50 \%)$, peserta didik dengan kategori cukup aktif 2 orang $(5,5 \%)$, peserta didik dengan kategori kurang aktif tidak ada (0\%). Sedangkan aktivitas belajar secara klasikal diperoleh sebesar 8,71 yang berada pada kategori aktif. Hasil Belajar Siklus I,Berdasarkan hasil observasi dan evaluasi diketahui hasil belajar peserta didik pada siklus I dapat dipaparkan bahwa, peserta didik yang tuntas pada aspek pengetahuan sebanyak 28 orang $(77,8 \%)$ dan peserta didik yang tidak tuntas sebanyak 8 orang $(22,2 \%)$. Adapun rinciannya sebagai berikut : 9 peserta didik (25\%) dengan kategori sangat baik, 11 peserta didik (30,5\%) dengan kategori baik, 8 peserta didik $(22,2 \%)$ dengan kategori cukup, 8 peserta didik $(22,2 \%)$ dengan kategori kurang, dan tidak ada peserta didik $(0 \%)$ dengan kategori sangat kurang. Jadi hasil belajar aspek keterampilan secara klasikal pada siklus I ini sudah memenuhi KKM dari SMA Negeri 2 Singaraja, namun secara individu masih ada 8 peserta didik yang belum tuntas.

Sedangkan peserta didik yang tuntas pada aspek keterampilan sebanyak 32 orang (88.9\%) dan peserta didik yang tidak tuntas sebanyak 4 orang $(11,1 \%)$. Adapun rinciannya sebagai berikut : belum ada peserta didik dengan kategori sangat baik, 15 peserta didik (41,6\%) dengan kategori baik, 17 peserta didik $(47,2 \%)$ dengan kategori cukup, 4 peserta didik $(11,1 \%)$ dengan kategori kuran. Jadi hasil belajar aspek keterampilan secara klasikal pada siklus I ini sudah memenuhi KKM dari SMA Negeri 2 Singaraja, namun secara individu masih ada 4 peserta didik yang belum tuntas.

Hasil Belajar Siklus II, Berdasarkan hasil observasi dan evaluasi diketahui hasil belajar peserta didik pada siklus II dapat dipaparkan bahwa, peserta didik yang tuntas pada aspek pengetahuan sebanyak 36 orang $(100 \%)$ dan tidak ada peserta didik yang tidak tuntas. Adapun rinciannya sebagai berikut : 11 peserta didik $(30,6 \%)$ dengan kategori sangat baik, 22 peserta didik $(61,1 \%)$ dengan kategori baik, 3 peserta didik $(8,3 \%)$ dengan kategori cukup, dan tidak ada peserta didik (0\%) dengan kategori kurang. Jadi hasil belajar aspek pengetahuan secara klasikal pada siklus II ini sudah memenuhi KKM dari SMA Negeri 2 Singaraja dan seluruh siswa terkategori tuntas. Sedangkan peserta didik yang tuntas pada aspek keterampilan sebanyak 36 orang $(100 \%)$ dan tidak ada peserta didik yang tidak tuntas. Adapun rinciannya sebagai berikut : 3 peserta didik $(8,3)$ dengan kategori sangat baik, 29 peserta didik $(80,6 \%)$ dengan kategori baik, 4 peserta didik $(11,1 \%)$ dengan kategori cukup, tidak ada peserta didik dengan kategori kurang. Jadi hasil belajar aspek keterampilan secara klasikal pada siklus I ini sudah memenuhi KKM dari SMA Negeri 2 Singaraja, dan secara individu sudak terkategori tuntas.

\section{Simpulan}

Berdasarkan uraian diatas dapat ditarik bahwa aktivitas dan hasil belajar passing bola voli (passing bawah dan passing atas) meningkat melalui penerapan model pembelajaran kooperatif tipe TPS pada siswa kelas XI MIPA 4 SMA Negeri 2 Singaraja tahun pelajaran 2017/2018. Peneliti menyarankan agar guru PJOK menggunakan model pembelajaran tipe TPS karena dapat meningkatkan aktivitas dan hasil belajar teknik dasar passing bola voli hal tersebut terlihat pada peningkatan hasil belajar pada persentase hasil belajar peserta didik aspek keterampilan pada observasi awal sebesar 16,7\%. Kemudian diberikan tindakan pada siklus I menjadi $88,9 \%$. Karena pada siklus I masih ada peserta didik yang belum tuntas maka diberikan tindakan pada siklus II menjadi 100\%. Dari hasil analisis data tersebut, dapat dilihat terjadi peningkatan persentase hasil belajar dari observasi awal, siklus I dan siklus II. Persentase hasil belajar teknik dasar passing bola voli pada peserta didik kelas XI MIPA 4 SMA Negeri 2 Singaraja mengalami peningkatan sebesar $72,2 \%$ dari $16,7 \%$ (siswa tuntas) pada observasi awal menjadi $88.9 \%$ 
(tuntas) pada siklus I. Kemudian meningkat sebesar 11,1\% dari 89,9\% (siswa tuntas) pada siklus I menjadi 100\% (siswa tuntas) pada siklus II. Dan meningkat sebesar 83,3\% dari 16,7\% (siswa tuntas) pada observasi awal menjadi 100\% (siswa tuntas) pada siklus II.

Berdasarkan simpulan di atas, dapat peneliti sarankan beberapa hal, sebagai berikut: 1) Para guru penjas (olahraga) yang mengajar di kelas XI SMK dapat memanfaatkan Model Pembelajaran Kooperatif Tipe TPS (Think-Pair-Share) dalam pembelajaran passing bola volli.

\section{Daftar Pustaka}

Arimbawa, 2014. Implementasi Model Pembelajaran Kooperatif Tipe Think Pair Share (TPS Untuk Meningkatkan Aktivitas Dan Hasil Belajar Teknik Dasar Passing Bola Voli Pada Peserta didik Kelas 1 RPL SMKN 1 Giantar Tahun Pelajaran 2013/2014. Skripsi (tidak diterbitkan). Fakultas Olahraga dan Kesehatan, Universitas Pendidikan Ganesha Singaraja.

Arikunto, Suharsimi. 2008. Penelitian Tindakan Kelas. Jakarta:Bumi Aksara.

Badan Standar Nasional Pendidikan. 2007. Panduan Penyusunan Kurikulum Tingkat Satuan Pendidikan Jenjang Pendidikan Dasar Dan Menengah. Jakarta : BSNP.

------.2007 Peraturan Menteri Pendidikan nasional Republik Indonesia Nomor 412007 Tentang Standar Proses Untuk Satuan Pendidikan Dasar Dan Menengah. Jakarta: Badan Standar Nasional Pendidikan.

Barbara dkk, 2000 Teknik Dasar Passing dalam Permainan Bola Voli. Jakarta: PT Raja Grapindo Persada.

Bayu Saputra, 2014. Implementasi Model Pembelajaran Kooperatif Tipe Think Pair Share (TPS Untuk Meningkatkan Aktivitas Dan Hasil Belajar Teknik Dasar Passing Bola Basket Pada Peserta didik Kelas VIII B SMPN 1 Seririt Tahun Pelajaran 2013/2014. Skripsi (tidak diterbitkan). Fakultas Olahraga dan Kesehatan, Universitas Pendidikan Ganesha Singaraja.

Budhiarta, I Made Danu. 2008. Teori Praktek Permainan Bola Voli Dan Bola Voli Pantai. Singaraja: Universitas Pendidikan Ganesha.

Departemen Pendidikan Nasional, 2006. Kurikulum 2006 Standar Kompetensi Mata Pelajaran Pedidikan Jasmani. Jakarta : Departemen Pendidikan Nasional.Dimyati dan Mudjiono. 2006. Belajar dan Pembelajaran. Jakarta: Rineka Cipta.

Hamalik, Oemar. 2001. Proses Belajar Mengajar. Jakarta: PT Bumi Aksara. 2008. Kurikulum dan pembelajaran. Jakarta: PT Bumi Aksara.

Husdarta, H.J.S. 2009. Manajemen Pendidikan Jasmani. Bandung: Alfabeta.

Juliantara, I Kadek. 2012. Implementasi Model Pembelajaran Kooperatif Tipe Think Pair Share (TPS Untuk Meningkatkan Aktivitas Dan Hasil Belajar Teknik Dasar Passing Bola Voli Pada Peserta didik Kelas VIII G SMP Negeri 2 Selat Tahun Pelajaran 2012/2013. Skripsi (tidak diterbitkan). Fakultas Olahraga dan Kesehatan, Universitas Pendidikan Ganesha Singaraja.

Kanca, I Nyoman. 2010. Metodologi Penelitian Pengajaran Pendidikan Jasmani dan Olahraga. Singaraja: Universitas Pendidikan Ganesha.

Kementerian Pendidikan dan Kebudayaan. 2014. Buku Peserta didik Pendidikan Jasmani, Olahraga, dan Kesehatan SMA/MA,SMK/MA Kelas X. Cetakan Ke-1. Jakarta: Pusat Kurikulum dan perbukuan, Balitbang.

Kunandar, 2008. Penelitian Tindakan Kelas Sebagai Pengembangan Profesi Guru. Jakarta: PT Raja Grafindo Persada. 
Nurhasan dan Sukardjo. 1992. Evaluasi Pengajaran Pendidikan Jasmani Dan Kesehatan. Surabaya: Departemen Pendidikan Dan Kebudayaan Direktorat Jendral Pendidikan Tinggi Proyek Pembinaan Tenaga Kependidikan.

Permendiknas. 2007. Standar Proses Untuk Satuan Pendidikan Dasar dan Menengah. Jakarta: Badan Standar Nasional Pendidikan.

Sanjaya, Wina. 2009. Strategi Pembelajaran Berorientasi Standar Proses Pendidikan. Jakarta: Prenada Media Group.

Sudjana, Nana. 2006. Penilaian Hasil Proses Belajar Mengajar. Bandung: PT Remaja Rosdakarya.

Sugiyanto, dkk. 1998. Perkembangan dan Belajar Motorik. Jakarta:Departemen Pendidikan dan Kebudayaan.

Suprijono, Agus. 2009. Cooperative Learning Teori dan Aplikasi Paikem. Yogyakarta: Pustaka Belajar.

Syarifuddin, Aip. 1997. Pendidikan Jasmani dan Kesehatan untuk Kelas III SLTP. Jakarta : Depatemen Pendidikan dan Kebudayaan.

Trianto. 2007. Model-model Pembelajaran Inovatif Berorentasi Konstruktivistik. Surabaya: PT. Prestasi Pustaka.

-----. 2009. Mendesain Model Pembelajaran Inovatif Progresif. Jakarta: Prenada Media Group.

Undang-Undang Republik Indonesia No. 2 Tahun 2003 tentang Sistem Pendidikan Nasional. 2003. Jakarta: PT Arnas Duta Jaya.

Warniki. 2014. Implementasi Model Pembelajaran Kooperatif Tipe Think Pair Share (TPS Untuk Meningkatkan Aktivitas Dan Hasil Belajar Teknik Dasar Berguling (Roll)Senam Lantai Pada Peserta didik Kelas VII B SMP Negeri 6 Singaraja Tahun Pelajaran 2013/2014. Skripsi (tidak diterbitkan). Fakultas Olahraga dan Kesehatan, Universitas Pendidikan Ganesha Singaraja.

Wardana. 2015. Implementasi Model Pembelajaran Kooperatif Tipe Think Pair Share (TPS Untuk Meningkatkan Aktivitas Dan Hasil Belajar Teknik Dasar Passing Bola Voli Pada Peserta didik Kelas IX B SMP Negeri 3 Tejakula Tahun Pelajaran 2014/2015. Skripsi (tidak diterbitkan). Fakultas Olahraga dan Kesehatan, Universitas Pendidikan Ganesha Singaraja. 